\author{
Monika ŚLUFIŃSKA \\ Jagiellonian University, Kraków, Poland \\ Agnieszka NITSZKE \\ Jagiellonian University, Kraków, Poland
}

\title{
Activities of the Visegrad Group in the Context of the CFSP of the EU
}

\author{
Działalność Grupy Wyszehradzkiej \\ w kontekście WPZiB UE
}

\section{- Abstrakt •}

Grupa Wyszehradzka (V4) powstała by wspomóc starania państw Europy Środkowej - Polski, Czechosłowacji (od 1993 r. Czech i Słowacji) oraz Węgier o członkostwo w NATO i Wspólnotach Europejskich. Po pierwszych latach istnienia zakończonych osiągnięciem zakładanych celów, po 2004 r. musiała na nowo zdefiniować swoją rolę i zadania. Nowa formuła Grupy Wyszehradzkiej po 2004 r. zakładała ścisłą współpracę państw członkowskich na forum Unii Europejskiej. Strategia połączenia potencjałów państw V4 w negocjacjach na poziomie unijnym w założeniu jest słuszna, gdyż może prowadzić do zwiększenia znaczenia regionu $\mathrm{w}$ procesie decyzyjnym. W artykule omówiona została geneza i ewolucja V4 do 2004 r. Następnie przedstawiona została współpraca wyszehradzka w zakresie Wspólnej Polityki Zagranicznej i Bezpieczeństwa UE. W tekście analizie poddano konkretne wydarzenia rzutujące na bezpieczeństwo Europy w ostatnich latach. Analiza zaangażowania V4 w kształtowanie WPZiB UE została oparta na materiałach źródłowych, w tym przede wszystkim dokumentach wypracowanych przez orga-

\section{- Abstract •}

The Visegrad Group (V4) was formed with the aim to support Central European countries Poland, Czechoslovakia (since 1993 the Czech Republic and Slovakia) and Hungary in their efforts to join NATO and the European Communities. V4 had to redefine its role and tasks after 2004 having achieved the set objectives in the first years of its existence. The new format of the Visegrad Group made provisions for a close cooperation between member states within the European Union. The strategy of combining potentials of the V4 states in negotiations on the EU level is based on reasonable assumptions, as it may lead to an increased significance of the region in the decision-making process. The article discusses the genesis and evolution of the V4 up to 2004. Next there is presented Visegrad cooperation in the field of the Common Foreign and Security Policy of the EU. The text analysis specific issues projecting the safety of Europe in recent years. The analysis of the commitment of V4 in the shaping of the EU CFSP will be based on source materials, mainly on documents produced by the authorities of the Visegrad Group such as 
ny Grupy Wyszehradzkiej, takich jak programy prezydencji, oświadczenia, deklaracje i raporty roczne.

Słowa kluczowe: Grupa Wyszehradzka, Wspólna Polityka Bezpieczeństwa i Obrony (WPBiO), Wspólna Polityka Zagraniczna i Bezpieczeństwa (WPZiB), kryzys migracyjny presidency programmes, statements, declarations and annual reports.

Keywords: Visegrad Group (V4), Common Security and Defence Policy (CSDP), Common Foreign and Security Policy (CFSP), European Neighbourhood Policy (ENP), migration crisis

The Visegrad Group (V4), formed with the aim to support Central European countries - Poland, Czechoslovakia (since 1993 the Czech Republic and Slovakia) and Hungary in their efforts to join NATO and the European Communities, had to redefine its role and tasks after 2004 having achieved the set objectives in the first years of its existence. The new format of the Visegrad Group made provisions for a close cooperation between member states within the European Union. The strategy of combining potentials of the V4 states in negotiations on the EU level is based on reasonable assumptions, as it may lead to an increased significance of the region in the decision-making process. In the article, the following research questions are subject to analysis: Q1. What are the common interests of the Visegrad Group member states?; Q2. Do the V4 member states manifest mutual loyalty in supporting their proposals and initiatives within the EU institutions?; Q3. What is the actual impact of $\mathrm{V} 4$ on the EU policy?

The analysis of the commitment of V4 in the shaping of the EU CFSP will be based on source materials, mainly on documents produced by the authorities of the Visegrad Group such as presidency programmes, statements, declarations and annual reports.

Until the early 1990s, Poland had a limited experience in political or economic integration. One could refer here to historical processes, i.e., Polish-Lithuanian union, though in this particular case it is difficult to specify any analogies with the present-day integration processes. In the post-war period, Poland was forced to cooperate within the Soviet Bloc due to geopolitical reasons. The Council for Mutual Economic Assistance provided no actual chance of economic integration, being solely a tool for controlling trade between the former socialist countries. After the breakthrough of 1989, Poland and other countries of the region found themselves in a kind of a "void" both in terms of security and economy. It was possible to overcome this difficult situation by building new alliances, either official or unofficial. From the very beginning of the transition, Polish diplomacy made efforts to prevent Poland from isolation or marginalisation on the international arena. Two of these initiatives, namely the Visegrad Group and the Weimar Trian- 
gle, had a particular importance in this context. The former consisted of countries with a similar Communist-authority experience in the post-war period, whereas the latter was an example of overcoming past divisions and gave way for a cooperation between Poland and Western European countries. Importantly, neither the Visegrad Group nor the Weimar Triangle ever gained a fully institutionalised form and thus they remain forums of regional cooperation to this day.

The idea of regional cooperation between the three countries: Poland, Czechoslovakia and Hungary was officially proposed for the first time by president of Czechoslovakia Vaclav Havel during his visit in Poland in January 1990, where at a joint sitting of the Sejm and Senate he stated, "For the first time in history, we have a real opportunity to fill the great political vacuum that appeared in Central Europe after the collapse of the Hapsburg Empire with something genuinely meaningful. We have an opportunity to transform Central Europe from what has been a mainly historical and spiritual phenomenon into a political phenomenon" (Address given by Vaclav Havel to the Polish Sejm and Senate, 1990). Havel stated the necessity to establish a closer Polish-Czechoslovakian-Hungarian cooperation yet again on the following day at his speech in the Hungarian Parliament. The first meeting of presidents, prime ministers and foreign ministers took place in the spring of the same year in Bratislava. The meeting was also attended by members of parliament of the three countries. They were largely former oppositionists. Thus, a significant parliamentary aspect of the Visegrad cooperation has been initiated, which was particularly important in the following years due to the legal harmonisation of the Visegrad Group member states that would adapt them to the EU requirements (5. Spotkanie Komisji Administracji Publicznej i Polityki Regionalnej Parlamentów Państw Grupy Wyszehradzkiej z udziałem właściwych Komisji Parlamentów Stowenii oraz Chorwacji, 2013). Interestingly, the said meeting did not bring any specific statements despite being driven to a considerable extent by a willingness to strengthen the global position of Czechoslovakia who sought membership in Quadragonale, i.e., the Adriatic-Danube cooperation formed at the time by Yugoslavia, Hungary, Austria and Italy $\left(\right.$ Czyż, 2014) ${ }^{1}$. Already at that stage, this demonstrated certain discrepancies, which later resulted in the collaboration becoming weaker or even occasionally suspended. Nonetheless, after the meeting in Bratislava, preparations for the rapprochement of Central European countries took place in the following months. The document that officially consti-

${ }^{1}$ Czechoslovakia attained its objective and was admitted to the group, which hence changed its name to Pentagonale. A year later, it was also joined by Poland and the name was thus changed yet again, this time to Hexagonale. After the dissolution of Czechoslovakia and Yugoslavia, the forum was eventually renamed "the Central European Initiative", which remains valid to this day. 
tuted the cooperation was signed on 15 February 1991 in Visegrad, Hungary, by Presidents Vaclav Havel and Lech Wałęsa and Prime Minister Josef Antall under the name Declaration on Cooperation Between the Czech and Slovak Federal Republic, the Republic of Poland and the Republic of Hungary in Striving for European Integration (Deklaracja o wspótpracy, 1991). The said document determined basic objectives of cooperation that were to be executed together by all states in the following years: firstly, to restore full independence, democracy and liberty of the state; secondly, to eliminate all existing social, economic and spiritual manifestations of a totalitarian system; thirdly, to create a parliamentary democracy, a modern state, to respect human rights and basic human liberties; fourthly, to create a modern market economy; and fifthly, to become fully engaged in the European political and economic systems, as well as security systems and systems of legislation. The element that later proved important (if not the most important) was the formalisation of the commercial and economic cooperation by the V4 member states. The Declaration itself involved an announcement of a closer cooperation in this regard, "(...) in order to support free flow of labour force and capital, they shall develop economic cooperation, based on the principles of the free market and mutually beneficial trade in goods and services, moreover they shall strive to create favourable conditions for direct cooperation of enterprises and foreign capital investments, aimed at improving economic effectiveness" (Deklaracja o wspótpracy, 1991). This served as the basis for signing the Central European Free Trade Agreement (CEFTA) on 21 December 1992 in Cracow. The agreement provided for a creation of a free-trade area by 1 January 2001 and prohibited the use of nontariff measures that hinder trade between the state parties of the Agreement (Kisiel-Łowczyc, 2001). The economic integration and the determined trade liberalisation schedule were executed without major problems. The matter of political cooperation is somewhat different. In terms of the Visegrad cooperation, the period of 1993-1998 may be regarded as a wasted time. This was affected by several factors, the most important of which was the radicalisation of political life in Slovakia and a shift in its foreign policy towards Russia under the leadership of Prime Minister Vladimir Mečiar. Another issue is the divergence between other member states. In this regard, the words of Czech Prime Minister Vaclav Klaus were all the more striking. In 1992, in an interview for the French daily Le Figaro Klaus said that as an "artificial" process launched in East-Central Europe possibly by Brussels, Visegrad was of no concern to the Czech Republic (Kiss, 1997). Klaus's words were dictated by the belief shared by the Czech diplomacy, according to which Poland constitutes a burden and not an added value in the efforts to join the European Communities, since at that time, the Czech Republic and Hungary han- 
dled economic transition much better. The reluctance towards a closer cooperation manifested by the Czech Republic and Hungary was caused also by concerns about the entire process being dominated by Poland, which surpasses the other three countries in the aspect of area and demographic potential. In the second half of the 1990s, the political cooperation within the Visegrad Group was renewed. This proved possible after a change of the Slovakian government. The new Prime Minister Mikuláš Dzurinda decided to implement a shift in foreign policy and to reengage in the efforts to join NATO and the EU. The symbolic renewal of political cooperation in V4 took place on 21 October 1998 in Budapest, where the prime ministers of the $\mathrm{V} 4$ countries were to assemble at least twice a year. On 1 May 2004, the objectives set out in the Visegrad Declaration were attained by all the four countries - Poland, the Czech Republic, Slovakia and Hungary have all become member states of the $\mathrm{EU}^{2}$. This successful attainment put the future of the Visegrad Group into question. In that situation, it was agreed that the Visegrad forum should be continued and that the cooperation will be taken to the level of the EU to allow their interests in matters important to the region to be defended in a more effective way. On 12 May 2004 in Kroměřiž prime ministers of the four countries adopted a declaration of cooperation after their accession to the European Union. The declaration stated "The Visegrad Group countries are strongly determined to jointly contributing to the fulfilment of the European Union's common goals and objectives and to the successful continuation of the European integration. They reiterate their commitment to the enlargement process of the European Union. They are ready to assist countries aspiring for EU membership by sharing and transmitting their knowledge and experience. The Visegrad Group countries are also ready to use their unique regional and historical experience and to contribute to shaping and implementing the European Union's policies towards the countries of Eastern and Southeastern Europe" (The Kromér $i z$ Declaration, 2004). The above statement points out the willingness to join the Europeanisation process on two levels: the inner level within the EU and the foreign level by means of assisting in the expansion and sharing one's own experience with subsequent countries that express aspiration similar to those of the V4 member states in the early 1990s. Regarding the Common Foreign and Security Policy, an "active contribution" in the development of that very area of the EU cooperation was declared. The commitment to internal issues and to the foreign coopera-

2 Poland, the Czech Republic and Hungary have joined NATO on 12 March 1999, whereas Slovakia on 29 March 2004. NATO Members. Retrieved from: http://www.nato.int/nato-welcome/index.html\#members. 
tion of the EU is confirmed by another declaration adopted on 15 February 2011 in Bratislava on the $20^{\text {th }}$ anniversary of the establishment of the Visegrad cooperation (The Bratislava Declaration, 2011). The document stresses the need to improve the V4 visibility on the international arena by means of active promotion of closer relations between the EU and the member states of the Eastern Partnership and the Western Balkans, which includes assisting them in their European aspirations and engaging in the development of the Common Foreign and Security Policy and the Common Security and Defence Policy of the EU while taking the interests of the Central European region into consideration (The Bratislava Declaration, 2011).

The membership in the EU and NATO allowed the Visegrad Group member states to change their geopolitical situation in only several years. Once satellite states of the Soviet Union, they have become fully integrated global actors by taking part in operations of two organisations of key importance for international economic and military security. However, the way in which this potential will be used was and still is open to discussion due to various scenarios that come into play, which oftentimes depend on the current political situation in a given country. One should note that the Visegrad Group is not the only existing forum of cooperation between Poland, the Czech Republic, Slovakia and Hungary. Each of these countries is simultaneously engaged in several subregional initiatives with interests that are not always compatible. For instance, apart from the Visegrad collaboration, Poland takes part also in the operations of the Weimar Triangle together with Germany and France, as well as in the Council of the Baltic Sea States together with the Scandinavian countries, the Baltic states, Germany, Iceland and Russia. Another issue regarding the cooperation and defining common objectives is the foreign policy of the individual V4 states, which often depends on their economic interests or historical circumstances. One should also bear in mind that despite being an added value, the shared experience of political transition constitutes an area of competition between the Visegrad states within the EU in seeking financial support, particularly regarding cohesion policy resources. Due to the above conditions, finding common objectives for the V4 member states to focus their activity on is difficult, though not impossible. In many aspects, the European Union is an atypical international organisation where the decision-making process is particularly dependent on the ability to form official and unofficial coalitions (Hix, 2010). The area of the Common Foreign and Security Policy, including its component the Common Security and Defence Policy, is a specific dimension of cooperation, as it has a direct impact on the issues related to sovereignty and, thus, the member states are not willing to adopt far-reaching regulations (Hoffmann, 
1966), while for each of them it is important to ensure the highest security level possible and a high position on the international arena. As a rule, decisions regarding CFSP are taken with unanimity (Węc, 2016), which makes the ability to win over other states particularly important and that comes easier with coalition capacity. In this regard, the impact exerted by the V4 member states is average, as most often issues considered to be a priority for the East-Central Europe region are seen by other countries as insignificant or conflicting with their interests. This internal division within the EU regarding foreign policy can be exemplified by the implementation of the European Neighbourhood Policy (ENP). The V4 declarations accepted following the annexation to the EU stressed the willingness to commit to promoting cooperation with the countries of the Eastern neighbourhood, primarily with Ukraine, Moldavia and Georgia. Meanwhile, Eastern Europe has little meaning for most Western and Southern EU member states, as they focus on the Southern area of the Mediterranean Sea. For that very reason, the establishment of the Eastern Partnership, which is one of the dimensions of the European Neighbourhood Policy, was considered a success of Polish diplomacy that managed to acquire the support of Sweden and the Czech Republic, as well as to convince Germany to advocate that idea. The Eastern Partnership Programme, which was inaugurated on 7 May 2009 at a meeting of the European Council in Prague, is targeted at six countries, namely, Belarus, Ukraine, Moldavia, Georgia, Armenia and Azerbaijan (Barabasz, Piechocki, 2012; Mizerska-Wrotkowska, 2011). The actual implementation of the objectives of the Eastern Partnership and the level of involvement of the individual V4 member states, as well as the impact of V4 on the ENP reform are yet another issue.

An important element of the Kromériz Declaration of 2004 is the establishment of a rotating annual presidency of the Visegrad Group. Since then, each of the member states that consecutively assumed leadership over the Group is obliged to develop a separate programme concerning current activities that allows the V4 member states to maintain permanent cooperation. The last element that concludes every presidency is the annual summit of the prime ministers of the V4 countries held in June, during which activities are resumed and new tasks are determined. Apart from at least one official summit of the prime ministers at the time of a given presidency, another key tool of cooperation within the Visegrad Group are occasional unofficial meetings of prime ministers or other ministers (mainly foreign ministers) that aim to seek a common position or are held due to upcoming international events. A common element of a presidency are meetings at the level of deputy ministers of foreign affairs that lay the groundwork for official meetings of prime ministers (The Kroméríž Declaration, 2004). Collaboration 
between other ministers and national V4 coordinators, as well as within the Permanent Representations of the EU, NATO and consultations within, e.g., OSCE, the UN, the European Council, etc., can take place at the same time. The Guidelines on the Future Areas of Visegrad Cooperation (2004) determine four most vital areas of cooperation, which include: cooperation within the V4 area (strictly speaking); cooperation within the EU; cooperation within other partners; and cooperation within NATO and other international organisations. Such a broad framework of cooperation between the V4 member states places the declaration of commitment to cooperation as part of the intensification of operations under the Common Foreign and Security Policy (CFSP) not only in the context of cooperation within the EU (and the implementation of the "Wider Europe - Neighbourhood" policy in particular) or in the context of the EU's approach towards the Western Balkans, but also makes it fall into other areas of cooperation. What is more, consultations and coordination of actions arising from the Schengen cooperation that pertain largely to the security and management of external borders were taken into consideration as well (The Guidelines..., 2004). During the Polish presidency of 2004-2005, a meeting of defence ministers regarding defence and military matters was held in autumn 2004. At the meeting, the postulates of the Prague Capabilities Commitment (PCC) were confirmed to be fully accepted, the collaboration between defence industry companies was declared to be strengthened, and systematic consultations were agreed to be carried out in matters regarding international safety with particular focus on regional safety issues and the use of stabilisation and peace missions to this end. Furthermore, the need for employing the capabilities of the EU agencies that deal with the development of the defensive potential, particularly the European Defence Agency (EDA) was also addressed. The willingness to continue the cooperation between national armaments directors was confirmed together with the strengthening of the collaboration between working groups at the ministerial level, such as TriStand, TRICOD, Asoc (2004/2005 Polish Presidency). Whereas the Hungarian presidency of 2005-2006 was dominated by common foreign policy matters and cooperation under the neighbourhood policy regarding Ukraine, but also other CIS member states and the Western Balkan countries. Among others, the necessity to support democratic reforms in Ukraine was noted, since in July 2005 a meeting between the foreign ministers of the V4 countries and the foreign minister of Ukraine took place, aiming at laying the groundwork for a summit of prime ministers of these countries. As for the Western Balkan countries, consideration was given to the necessity to support their aspirations to the EU membership. Moreover, the Visegrad Group confirmed the willingness to cooperate with the CIS yet again, concluding that 
sharing own experience gained during the social, political and economic transitions may prove particularly useful for the countries of that region. During the Hungarian presidency, focus was also put on the cooperation not only between V4 and both Austria and Slovenia but also the member states of the Nordic Council (2005/2006 Hungarian Presidency: Report). Similar declarations and resulting actions were proclaimed and implemented during the consecutive Slovakian presidency of 2006-2007. Here, seeking coordination of V4 activities in supporting Ukraine's efforts to join the EU and NATO was still the main priority alongside improving V4 activity in the Western Balkans as part of the implementation of the provisions of the Western Balkans conference that took place in Budapest on 11 October 2005. The aim of the Slovakian presidency of V4 was to improve further effective implementation of the Common Foreign and Security Policy (CFSP) and the European Security and Defence Policy (ESDP) by attempting to converge views of the V4 member states in their approach to the said areas. The Visegrad Group also declared support for the CSDP development by strengthening the collaboration within the transatlantic security community (2006/2007 Slovak Presidency). The Czech presidency of 2007-2008 pertained mostly to the strengthening of the collaboration between the Visegrad Group, Austria and Slovenia (V4+2), as well as to promoting common endeavours with, i.a., the Nordic Council member states, the Baltic states, Ukraine, Moldavia and Japan (2007/2008 Czech Presidency). These operations were continued (V4+) during the subsequent Polish presidency of 2008-2009, when the collaboration was improved and the instrument was maintained, as it was considered vital for strengthening of the political transition processes in, i.a., Belarus, Ukraine, Moldavia and the countries of the South Caucasus. Moreover, in line with the conclusions of the European Council of December 2007, during the Polish presidency steps were undertaken by the V4 countries to confirm that the Western Balkan countries ought to continue their integration with the EU. Additionally, a significant objective of the Polish presidency at that period was to determine and implement a consistent position that accepted the "open door" policy towards Ukraine and Georgia by means of working operations and to ensure commitment to promoting international security strategy in the relations between Russia and the Caucasus. The Polish presidency has made a considerable contribution to the issue of Ukraine by promoting this country with consideration to prospective membership both due to consultations regarding Ukraine's participation in the operations of the EU institutions or Community policies, and the V4 support of Ukraine's aspiration to become a member of the Energy Community (2008/2009 Polish Presidency). During the Hungarian presidency of 2009-2010, the focus of joint activities taken by V4 was put on sup- 
porting the accession of the Western Balkan countries into the EU and ensuring their integration with NATO, at the same time indicating a model that could be used in the future, i.e., the efficient accession process undertaken by Croatia. What is more, during the Hungarian presidency of V4 a suggestion to engage in supporting accession negotiations conducted by Turkey with the EU was made, since according to Hungarian politicians a perspective of being a member of the EU should motivate Turkish policy-makers to advance reforms necessary for that country. The Hungarian presidency also made provisions for assisting the Former Yugoslav Republic of Macedonia in strengthening of its ties with the EU and in seeking full membership in NATO. Moreover, the Hungarian presidency of V4 anticipated support provided by the Visegrad Group to Bosnia and Herzegovina's and Montenegro's efforts aiming at joining NATO, but also at strengthening the relation between NATO and Serbia while offering support to Albania and Montenegro in continuing their operations after the ratification of the SAA. The Hungarians did not refrain from taking steps for the benefit of the Eastern Partnership, claiming that the unique experience of the V4 member states in establishing relations with the EU can be helpful for Ukraine, Belarus and Moldavia alike, which are undergoing such process (2009/2010 Hungarian Presidency: Annual Report). The Slovakian presidency of 2010-2011 regarding security and defence merely concerned promoting the participation of the V4 countries both in civilian and military activities, as well as those related to the crisis response on the international arena. The Slovakians also proposed a resumption of negotiations on establishing the EU battlegroup consisting of $\mathrm{V} 4$ countries and arranging joint military exercises, which was accepted by all the ministers of national defence of the V4 countries. Moreover, risks related to cyberterrorism and issues related to the rebirth of radical views and groups worldwide were discussed (Annual Implementation Report, 2010/2011). Similar issues prevailed during the Czech presidency of 2011-2012, when the idea of creating the battlegroup was addressed again with the date of establishment set at the first half of 2016. What is more, the work related to the programme of the Eastern Partnership and the aid for the Western Balkans was continued (Innovative Visegrad, 2011/2012). As for the foreign policy of the subsequent Polish presidency of 2012-2013, the main focus was put on current European matters. Positions of the V4 countries concerning preparations for the European Council, the Foreign Affairs Council (FAC) and the General Affairs Council (GAC) were coordinated. At the very same time, the presidency was dominated by sectoral cooperation within V4, which mostly pertained to the matters related to the future cohesion policy, regional policy and strategic programming. Furthermore, the Polish presidency continued a process initiated during 
former presidencies led by the Czech Republic and Slovakia related to the presence of the Visegrad Group in the region and the launch of a special programme of the International Visegrad Fund concerning the Eastern Partnership, since further promotion of $\mathrm{V} 4$ cooperation and expansion of the said cooperation with activities and programmes that provide support to the Eastern Partnership was a long-term task of the V4 member states significant to Poland. During the Polish presidency, consultations were held with the European External Action Service (EEAS) and a competent Directorate General of the European Commission (DG DEVCO) concerning the task schedule for the Eastern Partnership programme. As for the contacts with the Western Balkans, Poland proposed to establish cooperation with Croatia (following accession of the latter to the EU) on the V4+ forum, which could contribute to activities supporting European aspirations of other Western Balkan countries. One of the other issues addressed during the Polish presidency was the representation of the V4 member states among the staff of the European External Action Service (EEAS), thus suggesting that joint actions should be taken to recruit diplomats from national services of the V4 countries to the EEAS. The necessity to attain common positions and to present them on international fora (i.a., UN, EU, NATO, OSCE) was stressed and encouraged among the V4 member states. Another addressed issue was the fight against terrorism, in which case the Polish presidency, similarly to former ones, ended in a declaration made by all the V4 member states to undertake actions aiming at strengthening, improving and coordinating antiterrorist systems within V4. Poland also suggested intensification of actions taken by the V4 countries within the UN by introducing the practice of consulting the heads of the UN facilities of the V4 member states and directors of the departments for UN affairs of the Ministry of Foreign Affairs in Warsaw on ongoing basis, and by maintaining permanent expert-level contact within V4 in matters covered by the agenda of the Security Council, the General Assembly and its committees, as well as specialist agencies and organisations (2012/2013 Polish Presidency). During the consecutive Hungarian presidency of 2013-2014, the formerly initiated tasks were continued and attempts were made to ensure that the collaboration on security and defence becomes the main focus of actions taken by the $\mathrm{V} 4$ countries, largely within the framework of sectoral cooperation. This was related to concerns about the security and stability of Europe and its neighbours in the context of the ongoing armed conflict in Ukraine. In the course of the preparations for the European Council in December 2013, the foreign ministers and the prime ministers of the V4 member states issued a statement regarding the importance of CSDP in international crisis management, whereas the ministers of national defence agreed that it was necessary to organise annual 
joint military exercises as of 2015. It was also agreed that the battlegroup formed by the V4 countries ought to serve as the basis for regional deployment of forces within NATO and the EU and could also be used during military missions. Concurrently, on 24 June 2014, the prime ministers of the V4 have adopted the socalled Budapest Declaration, which provides a fresh impetus in the field of security cooperation. The new strategy not only assumes joint military exercises and training, but also an increasingly closer cooperation in the defence industry. As for the matters of collaboration on the V4+ forum, meetings of experts and foreign ministers of countries, such as, Denmark, Estonia, Finland, Iceland, Latvia, Lithuania, Norway and Sweden were launched. The first meetings were held in Budapest on 21 January 2014. An interesting event within the framework of V4-Japan cooperation was a seminar on security that took place on 4 February 2014 in Tokyo. Moreover, as the host of the V4 presidency at that time, Hungary co-organised and co-funded the $9^{\text {th }}$ GLOBSEC international security conference that took place between 14-16 May 2014 in Bratislava (2013/2014 Hungarian Presidency). The Slovakian presidency of 2014-2015 was a continuation of actions initiated during the Hungarian presidency, while relations within V4 were dominated at that time by migrant issues. The Slovakian diplomacy organised numerous meetings at various levels (involving prime ministers, foreign ministers and experts). These debates resulted in a common position of the V4 countries regarding the implementation of obligatory immigrant quotas. Another significant event that affected the Slovakian presidency was the Russian-Ukrainian conflict. The V4 member states supported Ukraine by launching a project called V4 Roadshow in Ukraine in 2014 with the aim to facilitate Ukrainian public administration reforms and allocated about EUR 1,240,000 from the Visegrad Fund at the very same year for programmes supporting Ukraine. Apart from the commitment to the Eastern Partnership, the Slovakian presidency confirmed yet again the willingness to provide aid to the Western Balkan countries by launching an initiative called Western Balkans Expert Network, under which a seminar in Omšen on 13-15 October 2014 was held (among others) including a training course for judicial staff. Furthermore, in the time frame discussed above, the Slovakian diplomacy organised two summits of the prime ministers of the V4 member states in the socalled "expanded format". On 9 December 2014, a meeting took place in Bratislava attended by the president of the Swiss Confederation Didier Burkhalter, covering the issues of cooperation between the V4 member states and Switzerland with a particular focus on the co-funding provided by Switzerland to projects related to the Eastern Partnership developed by the International Visegrad Fund. The summit resulted in a common declaration that was proclaimed after the meeting of the 
prime ministers of the V4 countries and the president of the Swiss Confederation. The Slovakian presidency ended with a summit of the prime ministers of the V4 member states on 19 June 2015 in Bratislava with the presence of president of the French republic François Hollande as the guest of honour. The main subjects discussed at the meeting included the preparations for the $21^{\text {st }}$ Global Climate Conference planned for December 2015 in Paris and current issues, such as the matter of common security and defence policy within the EU and problems arising from the migrant crisis. Apart from this particular event, meetings between the heads of states of the V4 countries and the presidents of Ukraine and Germany took place on 16 November 2014 in Bratislava. Another important event on the V4+ forum was the meeting between the foreign ministers and the delegation of the Republic of Korea that occurred on 17 July 2014 in Bratislava, during which a financial contribution of EUR 336,000 allocated by Korea to the V4 countries with the aim to support several projects for the Western Balkans financed by the International Visegrad Fund was acknowledged. Between July 2014 and June 2015, meetings between ministers of defence and military experts were also held, which brought a recommendation for the EU member states to ensure a closer cooperation within the European security strategy (Report of the Slovak, 2014/2015). The last full presidency of 2015-2016 was led by the Czech Republic with focus on areas where cooperation has been maintained throughout former presidencies. The prevailing issues concerned the migrant crisis, which was a subject that dominated the subsequent three summits of the prime ministers of the V4 member states: the extraordinary summit on migration on 4 September 2015, the summit on the occasion of the $25^{\text {th }}$ anniversary of the formation of the Visegrad Group on 15 February 2016, and a closing summit on 8 June 2016 in Prague. The migrant crisis was also the cause of many meetings arranged between foreign ministers, interior ministers and defence ministers, whereas final documents received during those meetings confirmed the voluntary nature of solidarity activities of the EU member states to be a sensible solution and negated the obligatory mechanism of accepting immigrants or refugees by member states, which was imposed by France and Germany. At the same time, they recommended protection of the EU external borders. As the advocate of the Visegrad Fund as an important tool for implementing V4 programmes, the Czech diplomacy organised a conference on 25 May 2016 in Prague to which present and potential donors were invited. An unquestionable success of the Czech presidency was the final establishment of the V4 battlegroup and its certification. The cooperation within the V4 + format was also continued, particularly with the countries of the Nordic Defence Cooperation (NORDEFCO) and the USA. In conclusion, the analysis of activities taken dur- 
ing subsequent presidencies from the time of the proclamation of the Kromériz Declaration in 2004 shows that the V4 member states use all the available instruments necessary for conducting operations in the area of the Common Foreign and Security Policy. These include not only official summits of prime ministers, foreign ministers or defence ministers, but also working meetings of experts concerning both execution of actions at the level of data collection, analytical level, expert level or even military level. The most commonly implemented action is the collaboration with countries that apply or aspire for the EU or NATO membership, which consists in supporting reforms vital for pursuing their European or Euro-Atlantic objectives, as in the case of the Western Balkan countries. Similar actions pertain to Belarus, Ukraine, Moldavia and the South Caucasus where V4 acts as a strong advocate for democratic transitions. At the same time, it seems that the implementation of the Eastern Partnership has become a long-term project of V4. The constant policy of the Visegrad Group is to attempt at reaching consensus and establishing a common position of the V4 member states regarding preparations for the European Council, the Foreign Affairs Council or the General Affairs Council. It seems also that the intention of the V4 member states is to promote possible common concepts and proposals that reflect common interests of the Visegrad Group, though one ought to take into account the divergence of the national interests of individual V4 member states or priority setting that depends on the international situation (2015/2016 Czech Presidency).

Over the last five years, after the events of the Arab Spring and the Ukrainian crisis, significant changes have taken place in the global environment, resulting in a necessity to redefine the EU security strategy both internally (The European Agenda on Security, 2015) and externally (The EU Global Strategy Policy on Foreign and Security Policy, 2016). Both the Arab Spring and the Ukrainian crisis and their implications proved yet again how difficult it is to develop a common position within the EU. Differences between the member states regarding reaction and methods for tackling the crises triggered a crisis within the EU. Particularities of individual states pertaining to the execution of foreign and security policy have shown that the idea of CFSP is still far from solidarity. The Visegrad Group has taken a stance regarding both crises in an attempt to win over other EU member states, with varying effects. As a process of democratisation of the North African countries, the Arab Spring was not controversial as such and found full support in the European Community. Nevertheless, the consequences of the Arab Spring, including mass migrant influx largely from Syria, where the Arab Spring ended in a tragic civil war, have brought to light substantial differences between the member states. In 2015, in the face of an unusual migratory pressure, the European 
Commission proposed a mechanism for relocating immigrants arriving in Europe that would allow to ease the load on the Southern countries. On 22 September 2015, the European Council accepted the proposal of the European Commission under which Poland should admit 5,082 individuals, the Czech Republic - 1,591, Slovakia - 802 and Hungary - 1,294 (Council Decision (EU) 2015/1601). The new Polish government that has emerged from the parliamentary election in October has put to question the commitments made by its predecessors and launched an active campaign for a voluntary refugee admission system. To this end, Polish diplomacy has activated the Visegrad Group and over the following months asylum and migration policy of the EU has become one of the prevailing subjects on the V4 forum. On 3 December 2015, at the meeting of the heads of the V4 governments with the president of South Korea in Prague it was decided, that "The December European Council will be an opportunity to proceed further also in addressing the migration-related challenges and their root causes. This implies allocating adequate financial resources in the European Union budget, while other essential European policies, namely growth-oriented instruments such as cohesion policy, must not be affected. Any proposals that would follow such logic will meet our resolute rejection" (Joint Statement, 2015). The aim of the identification of a conflict between the EU asylum policy and cohesion policy was largely to affect the public in the $\mathrm{V} 4$ countries by creating an impression that asylum policy was to be funded at the expense of the development of East-Central Europe. Subsequent summits of 2016 were also dominated by this issue. The migration crisis was declared at the February summit to be a problem affecting the entire EU (Joint Statement on Migration, 2016), though to a different extent, yet at the June summit it was noted, that "With migration remaining the key challenge of the day, the Visegrad Group countries are convinced that it is essential to seek common and coherent European solutions which focus on tackling the root causes of the current migratory pressure, including ending of war in Syria and Iraq and stabilising of situation in Libya. (...) The countries of the Visegrad Group believe that the objective of the EU policy should be to ensure the reduction of the mixed migratory pressure on Europe by identifying genuine asylum seekers and through an integrated set of CFSP/CSDP/Development policy tools including the consideration of establishing of hotspots outside the territory of the EU and the protection of external borders" (Joint Statements of the Heads, 2016). This approach to the issue of the migrant crisis was subject to criticism by most EU member states as it demonstrated a lack of understanding of the idea of European solidarity.

The situation was thoroughly different when it comes to the reaction of V4 to the Ukrainian crisis, which was a subject raised at almost every V4 meeting held 
in 2014 regardless of its level. However, according to a documentation analysis, the interest of the Visegrad Group was highly superficial and limited merely to expressing concern with the development of events in Ukraine and the possible escalation of the conflict. The reaction of $\mathrm{V} 4$ to the situation in Ukraine is problematic, as on one hand, historical experience calls for maintaining utmost cautiousness in relations with Russia, yet on the other, there are also economic interests. For that very reason, two approaches within V4 can be determined: the Polish approach and the Czech-Slovakian-Hungarian approach (Kucharczyk, Mesežnikov, 2015). In this regard, the position that thoroughly condemned Russia's actions, which was adopted by Poland, can be regarded as the most radical. Poland was also the main advocate of imposing economic sanctions on Russia on the EU forum. Poland's policy was driven largely by loyalty towards Ukraine and a concern about further destabilisation of the largest Eastern neighbour. Due to numerous economic links the other V4 countries avoided making any unambiguous statements or providing unequivocal support to Ukraine in fear that their relations with Russia might become sour. Additionally, in January 2015, the so-called "Slavkov Triangle" was formed as a new regional cooperation format involving Austria, the Czech Republic and Slovakia with the official aim to promote economic cooperation including transport and energy, though in fact, to facilitate rapprochement to Russia (Kałan, 2015).

Here, one should also note the positive aspects of military cooperation. The first plans for creating a battlegroup by the V4 member states appeared as early as in 2007, though they proved unsuccessful at the time (Ciupiński, 2014). This idea came to the fore in 2013, when a letter of intent on joint establishment of the European Union battlegroup was signed. The battlegroup was designed to serve in the first half of 2016 (Lorenz, 2013). The plan was successfully implemented and on 18 November 2015 in the Land Operations Centre in Cracow the V4 EU Operational and Tactical Command was inaugurated. The command comprising Polish, Czech, Slovakian and Hungarian soldiers began its half-year call of duty on 1 January 2016. Poland provided a main battalion, support units and operational command composed of 950 soldiers in total. The Czech Republic delegated 750 soldiers, while Hungary and Slovakia 400 each. The EU Battlegroups are intended to participate in humanitarian missions, preventive missions and stabilisation missions with the aim to enforce or maintain peace. In the case of a decision to intervene, a battlegroup must respond within 10 days of that date and should be prepared for sustainable operation for 30 days, optionally extendable to 120 days.

In conclusion, in the face of crises that have brought or might bring in the future serious implications for both military and non-military security of the East- 
Central Europe, the V4 countries are driven by pragmatism and specific interests. The migrant crisis proved that it is possible to develop a common position and to advocate it within the EU, oftentimes against the political line of the largest European countries. However, this raises a question regarding the cost of such policy. Due to the lack of a broader coalition capability within the EU, initiatives of this kind are bound to fail. Moreover, the lack of solidarity regarding pan-European issues might prove to result in the future in a lack of solidarity in matters significant to V4 member states. What is more, it should be noted that despite the improvement in the Visegrad cooperation observed since the end of 2015, its effectiveness is not regarded as satisfactory. This is largely due to political problems and image issues of Hungary and Poland on the European stage after the controversial changes in the political systems introduced by their governments. Another issue is the lack of internal cohesion among the V4 countries, which has become clear particularly due to the Ukrainian crisis. The unquestionable positive aspect here is the establishment of the battlegroup, which shows that at present implementing common measures in CFSP comes easier than taking a common position in a spirit of European cooperation.

\section{References:}

5. Spotkanie Komisji Administracji Publicznej i Polityki Regionalnej Parlamentów Państw Grupy Wyszehradzkiej z udziatem właściwych Komisji Parlamentów Słowenii oraz Chorwacji Warszawa, 28-29 stycznia 2013 r. Retrieved from: http://www.senat.gov. $\mathrm{pl} / \mathrm{gfx} /$ senat/userfiles/_public/k8/ue/wyszehrad/tekst_intro_pl.pdf.

2004/2005 Polish Presidency. Program for the Polish presidency of the Visegrad Group 2004/2005. Retrieved from: http://www.visegradgroup.eu/documents/presidencyprograms/2004-2005-polish-110412.

2005/2006 Hungarian Presidency. Programme for the Hungarian presidency of the Visegrad

Group 2005/2006. Retrieved from: http://www.visegradgroup.eu/documents/presidency-programs/2005-2006-hungarian-110412.

2006/2007 Slovak Presidency. The Programme of Slovakia's V4 Presidency 2006/2007. Re-

trieved from: http://www.visegradgroup.eu/documents/presidency-programs/20062007-slovak-110412.

2007/2008 Czech Presidency. Czech Presidency of the Visegrad Group. Retrieved from: http:// www.visegradgroup.eu/documents/presidency-programs/2007-2008-czech-110412.

2008/2009 Polish Presidency. Programme of the Polish Presidency of the Visegrad Group. Retrieved from: http:/www.visegradgroup.eu/documents/presidency-programs/20082009-polish-110412.

2009/2010 Hungarian Presidency - Annual Report. Activities of the Hungarian Presidency of 
the Visegrad Group July 2009-June 2010. Retrieved from: http://www.visegradgroup. eu/documents/annual-reports/2009-2010-hungarian-110412.

2012/2013 Polish Presidency. Visegrad 4 Integration and Cohesion. Retrieved from: http:// www.visegradgroup.eu/documents/presidency-programs/2012-2013-polish.

2013-2014 Hungarian Presidency. Hungarian Presidency in the Visegrad Group (2013-2014). Retrieved from: http://www.visegradgroup.eu/documents/presidency-programs/ 20132014-hungarian.

2015-2016 Czech Presidency. V4 Trust-Program for the Czech Presidency of the Visegrad Group (July 2015-June 2016). Retrieved from: http://www.visegradgroup.eu/documents/presidency-programs/20152016-czech.

Address given by Vaclav Havel to the Polish Sejm and Senate (Warsaw, 25 January 1990). Retrieved from: http://www.cvce.eu/en/obj/address_given_by_vaclav_havel_to_the_ polish_sejm_and_senate_warsaw_25_january_1990-en-d639c9ab-79ce-41d9-87674 a9bd804ec35.html.

Annual Implementation Report of the Program of the Presidency of the Slovak Republic in the Visegrad Group (1 July 2010-30 June 2011). Retrieved from: http://www.visegradgroup.eu/documents/annual-reports.

Barabasz, A., Piechocki, M. (2012). Partnerstwo Wschodnie jako instrument polityki wschodniej UE?. Rocznik Integracji Europejskiej, 6, 258-269.

Ciupiński, A. (2014). Zdolności wojskowe Unii Europejskiej. Perspektywy grup bojowych. Rocznik Integracji Europejskiej, 8, 108-120.

Council Decision (EU) 2015/1601 of 22 September 2015 Establishing Provisional Measures in the Area of International Protection for the Benefit of Italy and Greece. (2015). Retrieved from: http://eur-lex.europa.eu/legal-content/EN/TXT/HTML/?uri=CELEX: 32015D1601\&from=EN.

Czyż, A. (2014). Grupa Wyszehradzka - 20 lat współpracy. Athenaeum, 42, 7-23.

Deklaracja o wspótpracy Czeskiej i Stowackiej Republiki Federacyjnej, Rzeczypospolitej Polskiej i Republiki Węgierskiej w dążeniu do integracji europejskiej, 1991. Retrieved from: http://www.visegradgroup.eu/documents/visegrad-declarations/visegrad-declaration-110412-2.

Hix, S. (2010). System polityczny Unii Europejskiej. Warszawa: PWN.

Hoffman, S. (1966). Obstinate or Obsolete? The Fate of the Nation-State and the Case of Western Europe. Daedalus, 95(3), 862-915.

Innovative Visegrad, Programme of the Czech Presidency of the Visegrad Group 2011-2012. Retrieved from: http://www.visegradgroup.eu/documents/presidency-programs/innovative-visegrad.

Joint Statement of the Heads of Governments of the Visegrad Group Countries: Towards Union of Trust and Action. (2016). Pobrane z: http://www.visegradgroup.eu/calendar/2016/joint-statement-of-the-160629.

Joint Statement on Migration. (2016). Retrieved from: http://www.visegradgroup.eu/calendar/2016/joint-statement-on.

Joint Statement on the Occasion of the First Summit of Prime Ministers of the Visegrad Group and the President of the Republic of Korea. (2015). Retrieved from: http://www.visegradgroup.eu/documents/official-statements/joint-statement-on-the. 
Kałan, D. (2015). The Slavkov Triangle: A Rival to the Visegrad Group? Biuletyn PISM, 19 (751), 1-2.

Kisiel-Łowczyc, A. (2001). CEFTA - Środkowoeuropejska Strefa Wolnego Handlu. In: E. Oziewicz (ed.), Procesy integracyjne we wspótczesnej gospodarce światowej (p. 81-102). Warszawa: PWN.

Kiss, Y. (1997). The Defence Industry in East-Central Europe: Restructuring and Conversion. Oxford: University Press.

Kucharczyk, J., Mesežnikov, G. (2015). Diverging Voices, Converging Policies: The Visegrad States' Reactions to the Russia-Ukraine Conflict. Prague-Warsaw: Heinrich-BöllStiftung.

Lorenz, W. (2013). Grupa bojowa UE - szansa na przełom we współpracy Grupy Wyszehradzkiej?. Biuletyn PISM, 38 (1014), 1-2.

Mizerska-Wrotkowska, M. (2011). Geneza i instytucjonalizacja Partnerstwa Wschodniego. In: A. Szeptycki (ed.), Między sasiedztwem a integracja. Założenia, funkcjonowanie i perspektywy Partnerstwa Wschodniego Unii Europejskiej (p. 43-63). Warszawa: Elipsa. NATO Members. Retrieved from: http://www.nato.int/nato-welcome/index.html\#members. Report of the Slovak Presidency of the Visegrad Group July 2014 - JUNE 2015. Retrieved from: http://www.visegradgroup.eu/documents/annual-reports.

The Bratislava Declaration of the Prime Ministers of the Czech Republic, the Republic of Hungary, the Republic of Poland and the Slovak Republic on the occasion of the 20th anniversary of the Visegrad Group, Bratislava, 15 February 2011. Retrieved from: http:// www.visegradgroup.eu/2011/the-bratislava.

The EU Global Strategy Policy on Foreign and Security Policy. Shared Vision, Common Action: A Stronger Europe, 2016. Retrieved from: http:/www.iss.europa.eu/uploads/media/EUGS.pdf.

The European Agenda on Security. (2015). Communication from the Commission to the European Parliament, the Council, the European Economic and Social Committee and the Committee of the Regions. Retrieved from: https:/www.cepol.europa.eu/sites/default/ files/european-agenda-security.pdf.

The Guidelines on the Future Areas of Visegrad Cooperation. Retrieved from: http://www. visegradgroup.eu/cooperation/guidelines-on-the-future-110412.

The Kromerriz Declaration, Declaration of Prime Ministers of the Czech Republic, the Republic of Hungary, the Republic of Poland and the Slovak Republic on cooperation of the Visegrad Group countries after their accession to the European Union (12 May 2004). Retrieved from: http://www.visegradgroup.eu/documents/visegrad-declarations/visegraddeclaration-110412-1.

Węc, J. (2016). Traktat lizboński. Polityczne aspekty reformy ustrojowej Unii Europejskiej w latach 2007-2015. Kraków: Księgarnia Akademicka. 